\title{
Toprak Mahsulleri Ofisi Alım Politikalarının Üreticilerin Buğday Üretim Uygulamaları Üzerine Etkisi: Ankara İli Gölbaşı İlçesi Örneği
}

\section{Impact of Turkish Grain Board Purchasing Policies on the Wheat Production Practices of the Producers: The Case of Gölbaşı District in Ankara Province}

\section{Özet}

$\mathrm{Bu}$ çalışmanın amacı, buğday alım faaliyetlerinde görevlendirilen Toprak Mahsulleri Ofisi'nin (TMO) alım politikalarının, üreticilerin buğday üretim uygulamaları üzerine etkisinin belirlenmesidir. 2011 yllında TMO'nun Avrupa Birliği (AB) uyum çerçevesinde buğday alım politikalarında değişikliğe giderek, fiziksel analizlerin yanında kimyasal kalite kriterlerinin de buğday alım fiyatında kriter olarak kullanılması uygulamasına başlamıştır. Araştırmada, Ankara İli Gölbaşı ilçesinde tabakalı tesadüfi örnekleme yöntemi ile belirlenen 91 tarım işletmesinden 2018 yılına ait veriler kullanılmıştır. Araştırma bulgularına göre, üreticilerin \%42,57'sinin satış fiyatına etki edecek kaliteyi artırıcı buğday üretim tekniklerini uygulamadığı belirlenmiştir. İşletmelerin \%40,37’sinin bir önceki sezonun buğday fiyatlarının sonraki yıl için üretim kararlarını önemli ölçüde etkilediği belirlenmiştir. TMO buğday alım politikalarında yapılan değişikliklerin, verimli ve kaliteli buğday çeşitlerinin, kaliteyi ve verimi artırıcı üretim tekniklerinin üreticilere aktarılması konularında yayım çalışmalarına devam edilmesi önerilebilir.

Anahtar Kelimeler: Ankara, Gölbaşı, alım politikaları, buğday, Toprak Mahsulleri Ofisi

Abstract

The aim of this study is to determine the impact of the purchasing policies of the Turkish Grain Board (TMO) assigned
Gönderilme Tarihi :

Kabul Tarihi
Sorumlu Yazar

Sinem TARHAN sinem.tarhan@tarimorman.gov.tr

iD 0000-0002-3009-0815

Yazar İlkay DELLAL dellal@ankara.edu.tr

iD 0000-0002-8534-3031 
to wheat purchase activities on the wheat production practices of producers. In 2011, the TMO changed its wheat purchase policies within the framework of European Union (EU) compliance and began to apply the use of chemical quality criteria as criteria in wheat purchase price as well as physical analysis. In the study, 2018 data from 91 farmers determined by the stratified random sampling method in Gölbaşı district of Ankara Province were used. According to the research findings, it was determined that $42.57 \%$ of the producers did not apply quality-enhancing wheat production techniques that would affect the sales price. It has been determined that the wheat prices of the previous season of $40.37 \%$ of producers significantly affect the production decisions for the following year. It may be suggested to continue publishing studies on the transfer of changes in TMO wheat purchase policies, productive and high quality wheat varieties, quality and yield enhancing production techniques to producers.

Key words: Ankara, Gölbaşı, purchase policies, wheat, Turkish Grain Board

\section{GİRIŞ}

Buğday, insan beslenmesindeki rolü, tarımsal üretimdeki payı, sanayiye hammadde sağlaması, ekonomik açıdan önemi, önemli sayıda üretici kitlesini de içine alması nedeniyle büyük öneme sahiptir (Karabak ve ark. 2013). Dünyada ve Türkiye'de ekim alanı ve üretim miktarı açısından ilk sıralarda yer alan buğday, günümüzde olduğu gibi gelecek yıllarda da stratejik bir ürün olma özelliğini devam ettirecektir (Akgün ve ark. 2011). Türkiye'nin her bölgesinde üretimi yapılan buğday; un haline geldikten sonra ekmek ve unlu mamullerde kullanılmasının yanında bisküvi, irmik, bulgur, makarna gibi birçok ürün şeklinde de değerlendirilmektedir. Aynı zamanda buğdayın öğütülmesi ile elde edilen kepek hayvan beslenmesinde kullanılmaktadır (Anonim, 2017a).

Dünya toplam buğday üretiminde 2019 yılında Avrupa Birliği (AB) ülkeleri \%20,3’lük pay ile ilk sırada yer alırken, bu sıralamayı Çin $(\% 17,4)$, Hindistan $(\% 13,5)$, Rusya $(\% 9,7)$ ve $\operatorname{ABD}(\% 6,8)$ takip etmektedir. Türkiye ise dünya buğday üretiminin \%2,5'ini karşılayarak 10. sırada yer almaktadır. 2019 yılında AB ülkelerinin dünya buğday ihracatından aldığı pay \%30,7 olurken, Rusya’nın payı $\% 17,7$ ve ABD’nin payı da \%15'dir (FAO, 2020). Dünya buğday üretimi ve ticaretinde önde gelen ülkeler $(A B, A B D$, Rusya gibi), dünya hububat sektöründe söz sahibi olmakta ve dış ticarette etkin bir rol oynamaktadır.

Her ülkenin tarım sektöründe yürüttüğü politikalar kendine özgü olmakta ve ülke tarımına yön vermektedir. Örneğin; uyguladığı tarım politikaları ile dünyada önemli bir konuma sahip olan AB, Ortak Tarım Politikası (OTP) ilkelerine göre hareket etmekte olup Ortak Piyasa Düzeni (OPD) kapsamında hububatta (makarnalık buğday, ekmeklik buğday, arpa, mısır) müdahale alım sistemini uygulamaktadır. AB'de hububat müdahale alımlarında; alım miktarları, kalite kriterleri, fiyat uygulamaları, iç ve dış satışlar, depolama gibi faaliyetlerin uygulanmasını Ödeme Kurumları gerçekleştirmektedir. AB Tüzüğü uyarınca, ekmeklik buğdayda müdahale alım miktarı $\mathrm{AB}$ bazında 3 milyon ton ile sınırlı tutulmakta ancak gerekli hallerde $\mathrm{AB}$ Komisyonu, belirlenen miktarın üzerinde ihale yoluyla da alım yapabilmektedir. Makarnalık buğday, arpa, mısır ve çeltikte ise tavan sınırlaması ve müdahale alım fiyatı $\mathrm{AB}$ Komisyonunca ihale yoluyla belirlenmektedir. ABD'de 6 yılda bir çıkarılan Tarım Kanunu çerçevesinde tarım politikaları uygulanmaktadır. ABD'de üreticilerin korunması, desteklenmesi ve gelir-fiyat dengesinin sağlanması amacıyla kurulan Ürün Kredi Kurumu (CCC - Commodity Credit Corporation), tarım piyasalarında önemli bir role sahiptir (Anonim, 2017b). ABD'de ürün piyasasının regülasyonu, lisanslı depoculuk ve borsalar yoluyla gerçekleşmektedir (Kaya, 2017). Rusya'daki hububat müdahale alımları, Birleşik Hububat A.Ş. (UGC) aracılığıyla gerçekleşmektedir. Üreticiler UGC'ye kayıt olduktan sonra Ulusal Emtia Borsasında ürünlerinin satışını yaparak yetkili lisanslı depolara ürünlerini teslim etmektedir (Anonim 2015).

Türkiye'de devlet tarafından alım faaliyetlerinde görevlendirilen Toprak Mahsulleri Ofisi (TMO), başta hububat olmak üzere faaliyet alanına giren tarım ürünlerinin alım ve satımını gerçekleştirmek, ürünlerin stok işlemlerini ve muhafazasını sağlamak, tarımsal ürün piyasalarında istikrarı sağlamak amaçlarını taşıyan Kamu İktisadi Teşekkülüdür (Anonim, 2020a). 
TMO’nun faaliyete başladığı 1938 yılında Türkiye’nin buğday üretimi yaklaşık 4,3 milyon ton iken TMO alım miktarı 0,121 milyon ton ve TMO alımının üretime oranı ise \%2,8'dir. Son 10 yll içerisinde Türkiye'nin buğday üretim miktarında önemli bir değişiklik olmamakla birlikte TMO alım miktarı 2018 yılında yaklaşık 2,4 milyon ton ve TMO alımının toplam buğday üretimine oranı da \%11,8 olarak gerçekleşmiştir (Çizelge 1). 2014 yılında piyasa fiyatları, TMO’nun öngördüğü hububat müdahale alım fiyatlarından daha yüksek gerçekleştiği için TMO müdahale alım fiyatları açıklanmamıştır (Anonim 2015).

Çizelge 1. Türkiye'de yıllar itibariyle buğday üretim miktarı, TMO alım miktarı ve TMO alımının üretime oranı

\begin{tabular}{|c|c|c|c|c|c|c|c|c|c|c|c|}
\hline Yillar & 1938 & 2010 & 2011 & 2012 & 2013 & 2014 & 2015 & 2016 & 2017 & 2018 & *2019 \\
\hline $\begin{array}{l}\text { Üretim miktarı (bin } \\
\text { ton) }\end{array}$ & 4,279 & 19.674 & 21.800 & 20.100 & 22.050 & 19.000 & 22.600 & 20.600 & 21.500 & 20.000 & 19.000 \\
\hline TMO alımı (bin ton) & 121 & 980 & 824 & 1.634 & 1.986 & - & 3.307 & 2.648 & 2.047 & 2.360 & - \\
\hline $\begin{array}{l}\text { Alımın Üretime Oranı } \\
(\%)\end{array}$ & 2,8 & 5,0 & 3,8 & 8,1 & 9,0 & - & 14,6 & 12,9 & 9,5 & 11,8 & - \\
\hline
\end{tabular}

*2019 TMO alım miktarı ve alımın üretime oranı açıklanmamıştır.

Kaynak: Anonim, 2020b

Türkiyede buğdayın pazarlanmasında TMO, tüccarlar, borsalar, makarna, un ve bulgur fabrikaları rol oynamaktadır. Üreticiler Çiftçi Kayıt Sistemi’nde (ÇKS) kayıtlı olan ürün miktarını TMO'ya satabilmekte veya emanete bırakabilme olanağına sahiptir. Ayrıca üreticiler ürünlerini uygun koşullarda lisanslı depolarda muhafaza edebildikleri gibi lisanslı depolara bıraktıkları ürünlerini de TMO'ya istedikleri zaman satabilmesi söz konusudur (Anonim, 2018).

Konuyla ilgili yapılan çalışmalar incelendiğinde; Kaya (2018) Türkiye'deki buğday piyasasında TMO alımlarının VAR modeliyle ekonometrik analizini yapmıştır. Taşcı ve ark. (2018) Ankara ilinde faaliyet gösteren un fabrikalarının buğday alım kriterleri, üretim ve pazarlama yapılarını incelemişlerdir. Dörtok ve Aksoy (2018) TMO alım miktarlarının buğday üretimi ve fiyata etkisini eşanlı model yöntemiyle ortaya koymuşlar, Karakuş (2017) TMO’nun uyguladığı politikaların Konya ili Çumra ilçesindeki hububat üreticilerinin kararlarına etkisini incelemiştir. Taşcı ve Oğuz (2014) Ankara ili Haymana ilçesindeki üreticilerin çeşit tercihlerini ve buğday üretim maliyetlerini ortaya koymuşlardır. Karabak ve ark. (2013) Ankara, Sivas ve Yozgat illerinde buğday üreticilerinin pazarlama davranışlarını araştırmışlardır. Konyalı (2008) buğdayda uygulanan tarım politikalarının Trakya Bölgesindeki üretici ve tüketiciler üzerine etkisini incelemiştir.

Literatürde; TMO'nun alım politikalarının üretici davranışlarına etkilerini araştıran çalışmalar bulunmakla birlikte TMO'nun buğday alımlarında 2011 yılından itibaren kalite kriterlerini dikkate alarak uyguladığ politikalarının, üreticilerin buğday üretim uygulamalarında değişiklikte bulunup bulunmama durumlarını inceleyen araştırmalara rastlanılmamaktadır. $\mathrm{Bu}$ çalışmada; TMO'nun uyguladığı alım politikalarının, Ankara ili Gölbaşı ilçesinde faaliyette bulunan buğday üreticilerinin buğday üretim teknikleri üzerine etkisinin belirlenmesi amaçlanmıştır.

\section{MATERYAL VE YÖNTEM}

Çalışmada; Ankara ilinde buğday üretiminin yoğun olarak yapıldı̆̆ı, yenilik ve teknolojilerin üreticiler tarafından yakından takip edildiği, lisanslı deponun ve TMO alım merkezinin bulunduğu Gölbaşı ilçesi araştırma alanı olarak belirlenmiştir. Çalışmanın ana materyalini, Ankara ili Gölbaşı ilçesinde buğday üreten 91 tarım işletmesinden yüz yüze anket yoluyla toplanan veriler 
oluşturmaktadır. Çalışmada, tarım işletmelerinin 2018 yılına ait verileri kullanılmıştır. Gölbaşı İlçe Tarım ve Orman Müdürlüğü’nden edinilen veriler doğrultusunda popülasyonu temsil edecek şekilde 7 mahalle (Runkuş, Bezirhane, Boyalık, Oyaca, Selametli, Emirler, Karagedik,) gayeli örnekleme yöntemiyle belirlenmiştir. Belirlenen 7 mahallenin buğday ekim alanlarının varyasyon katsayısı \%110 olarak hesaplanmıştır. Varyasyon katsayısının \%75'in üzerinde olması nedeniyle tabakalı tesadüfi örnekleme yöntemi kullanılmıştır. Örnek büyüklüğünün tespitinde aşağıdaki formül kullanılmıştır (Yamane, 1967).

$$
\mathrm{n}=\frac{\mathrm{N} \cdot \sum\left(N_{h} \cdot S_{h}^{2}\right)}{N^{2} \cdot D^{2}+\sum\left(N_{h} \cdot S_{h}^{2}\right)}
$$

n : Örnek büyüiklüğ̈̈̈,

N : Populasyondaki birim sayısı,

Nh : h'ncı tabakadaki birim sayısı,

$\mathrm{Sh}^{2}:$ h'nc1 tabakanın varyansı,

$\mathrm{D}^{2}=\left(\mathrm{d}^{2} / \mathrm{z}^{2}\right)$

D : Araştırıcı tarafından kabul edilebilecek maksimum hata miktarı veya örnek ortalaması ile populasyon ortalaması arasındaki fark,

$\mathrm{z}$ : $\mathrm{Bu}$ hata payına göre standart normal dağılım tablosundaki z değeridir.

Çizelge 2. İşletmelerin buğday ekim alanlarının tabakalara göre dağılımı ve anket sayıları

\begin{tabular}{|c|c|c|c|c|c|c|}
\hline Mahalleler & $\begin{array}{c}\text { Buğday } \\
\text { Ekim Alanı } \\
\text { (da) }\end{array}$ & $\begin{array}{c}\text { Gölbaşı Buğday } \\
\text { Ekim Alanı } \\
\text { İçindeki Oranı (\%) }\end{array}$ & $\begin{array}{c}\% 90 \mathrm{G} \\
\text { Tabakalar } \\
<15 \mathrm{da} \\
\text { 1. grup } \\
6\end{array}$ & $\begin{array}{l}\text { Aralı̆̆1 \%5 } \\
\text { Anket Sa } \\
\begin{array}{c}\text { 16-50 da } \\
\text { 2. grup } \\
5\end{array}\end{array}$ & $\begin{array}{l}\text { Payı ile } \\
\text { Dağılımı } \\
\begin{array}{l}51+\mathrm{da} \\
\text { 3. grup } \\
7\end{array}\end{array}$ & $\begin{array}{c}\text { Toplam } \\
\text { Anket Sayısı }\end{array}$ \\
\hline Bezirhane & 18318 & 14,1 & 4 & 5 & 4 & 13 \\
\hline Boyalık & 17993 & 13,9 & 5 & 4 & 4 & 13 \\
\hline Oyaca & 18670 & 14,4 & 5 & 3 & 5 & 13 \\
\hline Selametli & 17086 & 13,2 & 4 & 3 & 5 & 12 \\
\hline Emirler & 16333 & 12,6 & 4 & 3 & 4 & 11 \\
\hline Karagedik & 16004 & 12,4 & 4 & 3 & 4 & 11 \\
\hline Toplam & 129529 & 100 & 32 & 26 & 33 & 91 \\
\hline
\end{tabular}

Anket sonuçlarından elde edilen veriler tanımlayıcı istatistikler ve Likert tipi ölçeklendirme yöntemi kullanılarak değerlendirilmiştir. Ayrıca işletmelerin pazarlama davranışlarının ortaya konulmasında Ki-kare bağımsızlık testi kullanılmıştır. Ki-kare istatistiği formülü aşağıda gösterilmiştir (Saraçbaşı ve Kutsal 1986).

$$
X^{2}=\sum_{f=1}^{R} \sum_{j=1}^{C} \frac{\left(f_{i j}-f^{\prime}{ }_{i j}\right)^{2}}{f^{\prime}{ }_{i j}}
$$

: Gözlenen sıklıklar
: Beklenen siklıklar

R: Satır sayıs1

C: Sütun sayısı

\section{ARAŞTIRMA BULGULARI VE TARTIŞMA}

Araştırma kapsamındaki üreticilerin yaş ortalaması 53,83 olup \%36,26'sının 55-64 yaş aralığında ve \%57,14'ünün de ilkokul mezunu olduğu belirlenmiştir (Çizelge 3). Karabak ve ark. (2013) 2011 yılında Ankara ilindeki buğday üreticilerinin ortalama yaşının 52 olduğu, \%83,8'inin eğitim düzeyinin ise ilköğretim olduğunu 
belirtirken, Taşcı ve Oğuz (2014) Ankara ili Haymana ilçesinde yaptıkları çalışmada işletmedeki hane nüfusunun \%49,58'inin 15-49 yaş grubu arasında, \%47,23’ünün lisede okuyan veya mezun olduğunu belirtmiştir. Köksal ve Cevher (2015) Ankara ili Polatlı ilçesindeki buğday üreticilerinin ortalama 50,6 yaşında ve $\% 53$,4'ünün de ilkokul mezunu olduğunu bildirmişlerdir.

Çizelge 3. İncelenen işletmelerdeki üreticilerin yaş ve eğitim durumu (\%)

\begin{tabular}{|c|c|c|c|c|c|c|c|c|c|c|c|}
\hline $\begin{array}{c}\text { İsletme } \\
\text { Grupları }\end{array}$ & $25-34$ & $35-44$ & $45-54$ & $55-64$ & $65-+$ & Toplam & İlkokul & Ortaokul & Lise & $\begin{array}{c}\text { Üniversite } \\
\text { (önlisans-lisans) }\end{array}$ & Toplam \\
1. grup & 12,50 & 6,25 & 31,25 & 25,00 & 25,00 & 100,00 & 56,25 & 18,75 & 21,88 & 3,12 & 100,00 \\
\hline 2. grup & 3,85 & 15,38 & 19,23 & 50,00 & 11,54 & 100,00 & 65,39 & 19,23 & 7,69 & 7,69 & 100,00 \\
\hline 3. grup & 9,09 & 27,27 & 9,09 & 36,37 & 18,18 & 100,00 & 51,52 & 30,30 & 9,09 & 9,09 & 100,00 \\
\hline $\begin{array}{c}\text { İssletmeler } \\
\text { Ort. }\end{array}$ & 8,79 & 16,49 & 19,78 & 36,26 & 18,68 & 100,00 & 57,14 & 23,08 & 13,19 & 6,59 & 100,00 \\
\hline
\end{tabular}

İncelenen işletmelerde 32,8 yıldır aralıksız olarak buğday ekiminin yapıldığı belirlenmiştir. İşletmelerin \%40,37’si ile büyük çoğunluğu bir önceki üretim sezonundaki buğday satış fiyatına bakarak buğday üretimine devam etme kararı alırken, \%34,86'sı ise herhangi bir planlama yapmadan sonraki yıllarda buğday üretimine devam edeceğini belirtmiştir. Ayrıca alternatif ürünlerin satış fiyatı, buğday verimi de üretici kararlarını etkilemektedir (Çizelge 4). Bu bakımdan buğday üretiminin devamlılı̆̆ının sağlanmasında ürünün satış fiyatı önemli bir kriter olmaktadır.

Çizelge 4. İşletmelerin buğday üretimine devam edip etmeme kararını etkileyen faktörler (\%)

\begin{tabular}{|l|c|}
\hline \multicolumn{1}{|c|}{ Faktörler } & Ortalama \\
\hline Bir önceki üretim sezonu buğday satış fiyatı & 40,37 \\
\hline Herhangi bir kritere bakmaksızın her koşulda üretime devam etme & 34,86 \\
\hline Alternatif ürünlerin (arpa, çavdar) bir önceki üretim sezonu satı̧ fiyatı & 17,43 \\
\hline Bir önceki üretim sezonu buğday verimi & 4,58 \\
\hline Tarım ve Orman Bakanlığı’nın açıklamaları & 0,92 \\
\hline Komşu üreticilerin yönlendirmesi & 0,92 \\
\hline Girdi fiyatları & 0,92 \\
\hline Toplam & 100,00 \\
\hline
\end{tabular}

İncelenen işletmelerin \%69,66'sı buğdayını tüccara satarken, \%15,73'ü borsaya, \%14,61’i de TMO’ya buğday satışını gerçekleştirmiştir. Karakuş (2017) Konya ili Çumra ilçesindeki tarım işletmelerinin birinci parti satışlarında hububat satış yeri olarak ilk sırada tüccarı tercih ettiğini, ikinci parti satışlarında ise ilk olarak TMO'yu tercih ettiğini bildirmiştir. Benzer bir çalışmada Karabak ve ark. (2013) buğday işletmelerinin \%44,9’unun satış yeri olarak borsayı, \%24,1'inin tüccarı ve \%14,9'unun da TMO'yu tercih ettiğini belirtmişlerdir.
İncelenen işletmelerin \%77,53’ü ürününü hasattan hemen sonra satmaktadır. Hasattan hemen sonra satılan buğdayın ortalama satış fiyatı $0,89 \mathrm{TL} / \mathrm{kg}$ iken, hasattan bir müddet sonra satılan buğdayın satış fiyatı ise ortalama $1,25 \mathrm{TL} / \mathrm{kg}$ 'dır. Her iki satış zamanında da (hasattan hemen sonra-hasattan bir müddet sonra) borsaya ürününü satan üreticiler, TMO ve tüccara kıyasla daha yüksek fiyattan buğdayını satmıştır (Çizelge 5). Karakuş (2017) incelediği işletmelerin \%90'ının hububatı hasat zamanı sattığını, $\% 10$ 'unun da hasattan belli bir süre sonra sattığını bildirmiştir. 
Ki-kare analizi sonucunda, buğdayın satış zamanı ve satış fiyatı arasında istatistiksel açıdan anlamlı bir ilişki $(p<0,05)$ bulunmuş olup ilişkinin yönünü ve gücünü tespit etmek için yapılan korelasyon analizi sonucuna göre ise pozitif yönlü ve güçlü bir ilişki olduğu belirlenmiştir (Çizelge 5). $\mathrm{Bu}$ sonuca göre ürününü belli bir süre bekleten üreticiler, hasattan hemen sonra satan üreticilere göre buğdayı daha yüksek fiyattan satma imkanına sahiptir. Ancak üreticilerin fiyat farklılığı riskini göze alamaması, nakit ihtiyacının olması, ürününü depolayacak yeterli alana sahip olmaması, yeterli sermayesi bulunmaması gibi nedenlerle buğdayını hasattan hemen sonra satma eğilimindedir.

Çizelge 5. Üretilen buğdayın satış zamanı ve yerine göre satış fiyatındaki değişim

\begin{tabular}{|c|c|c|c|c|}
\hline Satış Zamanı & Satış Yeri & $\begin{array}{c}\text { Ortalama Satış Fiyatı } \\
(\mathrm{TL} / \mathrm{kg})\end{array}$ & $\mathbf{N}$ & Std. Sapma \\
\hline \multirow{4}{*}{$\begin{array}{l}\text { Hasattan hemen } \\
\text { sonra }\end{array}$} & Tüccar & 0,88 & 50 & 0,07 \\
\hline & Borsa & 1,02 & 7 & 0,16 \\
\hline & TMO & 0,90 & 12 & 0,10 \\
\hline & Toplam & 0,89 & 69 & 0,09 \\
\hline \multirow{4}{*}{$\begin{array}{l}\text { Hasattan bir } \\
\text { müddet sonra }\end{array}$} & Tüccar & 1,22 & 12 & 0,18 \\
\hline & Borsa & 1,31 & 7 & 0,14 \\
\hline & TMO & 1,15 & 1 & - \\
\hline & Toplam & 1,25 & 20 & 0,16 \\
\hline \multirow{4}{*}{ Toplam } & Tüccar & 0,94 & 62 & 0,18 \\
\hline & Borsa & 1,16 & 14 & 0,21 \\
\hline & TMO & 0,92 & 13 & 0,12 \\
\hline & Toplam & 0,97 & 89 & 0,19 \\
\hline $\begin{array}{l}\text { Ki-kare: } 111,363 \\
p=0,000\end{array}$ & \multicolumn{3}{|c|}{ Korelasyon katsayısı: $0,798, p=0,000$} & \\
\hline
\end{tabular}

İ̧letmelerin \%76,41 ile büyük çoğunluğu TMO’nun, $\% 8,99$ 'u borsanın, \%5,62'si de Tarım ve Orman Bakanlığı’nın buğday fiyatlarını belirleyen kuruluş olması gerektiğini düşünmektedir. Buğdayını tüccara satan işletmelerin \%79,03’ü, TMO’ya satış yapan üreticilerin
$\% 84,6$ 's1 ve borsaya ürününü satan üreticilerin $\% 57,13$ 'ü de buğday fiyatının belirlenmesinde TMO'yu uygun bulmaktadır (Çizelge 6). Bu duruma göre işletmelerin buğdayı sattıkları yer farklılık gösterse bile buğday fiyatını ilk sırada TMO’nun belirlemesi gerektiği görüşündedirler.

Çizelge 6. İncelenen işletmelerin buğday satışını yaptıkları yer ile buğday fiyatını belirlemesini istedikleri kuruluşların ilişkilendirilmesi (\%)

\begin{tabular}{|c|c|c|c|c|c|c|c|}
\hline \multirow{2}{*}{$\begin{array}{c}\text { Buğday Satı̧ } \\
\text { Yerleri }\end{array}$} & \multicolumn{6}{|c|}{ Kuruluşlar } & \multirow{2}{*}{ Toplam } \\
\hline & TMO & Borsa & $\begin{array}{l}\text { Tarım ve Orman } \\
\text { Bakanlığı }\end{array}$ & $\begin{array}{l}\text { Ziraat } \\
\text { Odaları }\end{array}$ & $\begin{array}{l}\text { Üretici } \\
\text { Birlikleri }\end{array}$ & Kooperatif & \\
\hline Tüccar & 79,03 & 8,06 & 4,84 & 3,23 & 4,84 & - & 100,00 \\
\hline TMO & 84,60 & 7,70 & - & - & - & 7,70 & 100,00 \\
\hline Borsa & 57,13 & 14,29 & 14,29 & 14,29 & - & - & 100,00 \\
\hline İşletmeler Ort. & 76,41 & 8,99 & 5,62 & 4,49 & 3,37 & 1,12 & 100,00 \\
\hline
\end{tabular}


TMO, 2011/2012 alım döneminden itibaren fiziksel analizlerin yanında kimyasal analizlere de yer vermiştir (Anonim 2015). TMO alım bareminde protein oranı fiyatlandırmaya etki eden kriterlerin başında gelmesine rağmen üreticiler protein oranının buğdayı satarken 5 . sırada fiyatta etkili olduğunu bildirmişlerdir. İncelenen işletmeler süne-kımıl tahribat oranının buğdayın satış fiyatına etki eden en önemli kriter olduğunu belirtmiştir
(Çizelge 7). Süne-kımıl ile mücadele edilmediğinde veya mücadele için geç kalındığında kalite kayıplarına sebep olmakta ve meydana gelen zarara bağlı olarak da üreticinin buğdayı daha düşük fiyattan satmasına neden olmaktadır. Taşcı ve ark. (2018) Ankara ilinde yaptıkları çalışmada, un fabrikalarının buğday alımlarında fiyatı etkileyen en önemli unsurun buğdayın süne emgi oranı olduğunu belirtmişlerdir.

Çizelge 7. İncelenen işletmelerin buğdayın satış fiyatına etki ettiğini düşündüğü kriterlerin ağırlıklı ortalaması

\begin{tabular}{|c|c|c|c|c|}
\hline \multirow{2}{*}{ Kriterler } & \multicolumn{3}{|c|}{ İşletme Grupları } & \multirow{3}{*}{$\begin{array}{c}\text { İşletmeler Ort. } \\
4,81 \\
\end{array}$} \\
\hline & 1. grup & 2. grup & 3. grup & \\
\hline Süne-kımıl tahribatı & 4,84 & 4,81 & 4,79 & \\
\hline Hektolitre ağırlı̆g 1 & 4,72 & 4,73 & 4,76 & 4,74 \\
\hline Buğday çeşidi & 4,69 & 4,58 & 4,88 & 4,73 \\
\hline Yabancı madde oranı & 4,66 & 4,65 & 4,82 & 4,71 \\
\hline Protein oranı & 4,75 & 4,62 & 4,67 & 4,68 \\
\hline Gluten kalitesi & 4,63 & 4,54 & 4,55 & 4,57 \\
\hline Rutubet oranı & 4,44 & 4,35 & 4,52 & 4,44 \\
\hline Satış tarihi & 3,97 & 4,19 & 3,88 & 4,00 \\
\hline Buğday çeşidinin yöresi & 2,38 & 3,38 & 2,64 & 2,76 \\
\hline
\end{tabular}

TMO'nun 2011 yılından itibaren buğday alım politikalarında kalite kriterlerini dikkate alarak fiyatlandırma uygulamasına geçmesi ile birlikte kaliteli buğdayın fiyatı diğer buğdaylara oranla daha yüksek değerden işlem görmeye başlamıştır. Bu politika değişikliği ile üreticilerin buğday üretim uygulamalarına etkisi Çizelge 8 'de gösterilmiştir. 1. ve 2. grupta incelenen işletmelerin büyük bir kısmı tarımsal uygulamalarında bir değişiklik yapmadığını belirtirken, 3. grup işletmelerin \%35'i buğday çeşidini değiştirdiğini belirtmiştir. Yetiştirme tekniklerinde (gübre miktarı, gübreleme zamanı) değişiklik yapan üreticiler buğdayda uyguladıkları gübre miktarını artırdıklarını, ayrıca buğdayda üst gübreleme zamanlarını Mart sonu-Nisan ayının ilk haftasında yaparken iklime bağlı olarak gübreleme zamanını yaklaşık 1 ay önceye çektiklerini, böyle bir uygulamayla buğdayın kalitesi ve veriminin daha da arttığını belirtmişlerdir. İşletmelerin \%8,91'i zirai mücadelede (ilaç miktarı) değişiklik yaptığını belirtirken, \%5,94’ü ise TMO'nun kaliteye dayalı alım sistemine geçmesinden haberdar olmadığını belirtmiştir.

Çizelge 8. TMO'nun buğdayda kaliteye dayalı alım sistemine geçmesi durumunun üreticilerin buğday üretim uygulamalarına etkisi (\%)

\begin{tabular}{|l|c|c|c|c|c|c|}
\hline \multicolumn{1}{|c|}{$\begin{array}{c}\text { İşletme } \\
\text { Grupları }\end{array}$} & $\begin{array}{c}\text { Herhangi bir } \\
\text { değişiklik } \\
\text { yapılmaması }\end{array}$ & Çeşit değişikliği & $\begin{array}{c}\text { Yetiştirme } \\
\text { tekniklerinde } \\
\text { değişiklik }\end{array}$ & $\begin{array}{c}\text { Zirai } \\
\text { mücadelede } \\
\text { değişiklik }\end{array}$ & $\begin{array}{c}\text { Bu konudan } \\
\text { haberinin } \\
\text { olmaması }\end{array}$ & Toplam \\
\hline 1. grup & 54,55 & 18,18 & 12,12 & 6,06 & 9,09 & 100,00 \\
\hline 2. grup & 46,43 & 25,00 & 17,86 & 7,14 & 3,57 & 100,00 \\
\hline 3. grup & 30,00 & 35,00 & 17,50 & 12,50 & 5,00 & 100,00 \\
\hline İşletmeler Ort. & 42,57 & 26,73 & 15,84 & 8,91 & 5,94 & 100,00 \\
\hline
\end{tabular}


İşletmelerin \%78 ile büyük bir kısmı TMO’nun buğdayda uyguladığı alım politikalarından memnun olmadığını belirtmiştir. Üreticilerin memnun olmamasının en önemli nedeni $(\% 67,61)$; TMO’nun buğday alımında belirlediği kalite kriterlerinin sağlanmamasına bağlı olarak ürünlerinin daha düşük fiyattan işlem görmesidir. İşletmelerin \%18,31'i TMO'nun analiz metotlarına güvenmediğini, \%9,86'sı TMO'nun alım süresinin sınırlı olduğunu ve \%4,28'i de ödemelerde gecikmenin olduğunu ifade etmiştir (Çizelge 9).

Çizelge 9. İşletmelerin TMO’nun alım uygulamalarından memnun olmama nedenleri (\%)

\begin{tabular}{|l|c|}
\hline \multicolumn{1}{|c|}{ Nedenler } & Ortalama \\
\hline Ürünün kalitesine göre fiyatının düşürülmesi & 67,61 \\
\hline Analiz metotlarına güvensizlik & 18,31 \\
\hline Alım süresinin sınırlı olması & 9,86 \\
\hline Ödemelerde gecikmenin olması & 4,23 \\
\hline Toplam & 100,00 \\
\hline
\end{tabular}

Üreticilerin TMO'nun buğday alım uygulamaları hakkındaki görüşlerini değerlendirmede 5'li likert ölçeğinden yararlanılmıştır. İşletmeler hububat fiyatlarının belirlenmesinde TMO'nun etkin rol oynadığını, kaliteye dayalı alım sistemine geçilmesinin olumlu bir gelişme olduğunu ve üretim kararlarında TMO'nun alım ve fiyat politikalarının önemli etkisi olduğunu düşünmektedir.
Ayrıca işletmeler TMO'nun ödemelerde üretici lehine faaliyette bulunması ve TMO'nun randevu sisteminin üreticiler açısından etkili çalıştığı konusunda kararsız kalmaktadır. TMO'ya buğday satışında bulunan işletmelerin TMO'nun uyguladığı politikalara katılım düzeyi ise ürününü TMO'ya satmayan işletmelere kıyasla daha yüksektir (Çizelge 10).

Çizelge 10. TMO’ya ürün satışı yapan ve yapmayan işletmelerin TMO’nun buğday alım uygulamaları hakkındaki görüşleri

\begin{tabular}{|c|c|c|c|}
\hline \multirow{2}{*}{ Görüşler } & $\begin{array}{l}\text { TMO'ya ürün satı̧ıı } \\
\text { yapan }\end{array}$ & $\begin{array}{l}\text { TMO'ya ürün satı̧̧ı } \\
\text { yapmayan }\end{array}$ & \multirow[b]{2}{*}{ Toplam İşletmeler Ort } \\
\hline & \multicolumn{2}{|c|}{ İşletmeler Ortalaması } & \\
\hline $\begin{array}{l}\text { TMO hububat fiyatlarının belirlenmesinde etkin rol } \\
\text { oynamaktadır }\end{array}$ & 4,31 & 3,76 & 3,84 \\
\hline $\begin{array}{l}\text { TMO'nun kaliteye dayalı alım sistemine geçmesi } \\
\text { olumlu bir gelişmedir }\end{array}$ & 4,15 & 3,72 & 3,79 \\
\hline $\begin{array}{l}\text { TMO'nun alım ve fiyat politikaları üreticilerin } \\
\text { üretim kararını etkilemektedir }\end{array}$ & 4,46 & 3,37 & 3,53 \\
\hline $\begin{array}{l}\text { TMO, ödeme şekli konusunda üretici lehine } \\
\text { faaliyette bulunmaktadır }\end{array}$ & 3,69 & 3,13 & 3,37 \\
\hline TMO’nun randevu sistemi etkili çalışmaktadır & 3,23 & 3,13 & 3,15 \\
\hline
\end{tabular}




\section{SONUÇ VE ÖNERILLER}

Tarım sektöründe önemli bir konuma sahip olan TMO'nun buğdayda uyguladığı politikalar, başta üreticiler olmak üzere tüccarlar, sanayiciler ve tüketiciler için bağlayıcı nitelikte olmakta, TMO'nun alım politikalarındaki değişiklikler ve aldığı kararlar buğday üreticilerinin üretim yapısı ve pazarlama davranışlarını doğrudan etkilemektedir. Üreticiler üretim planlaması yaparken önceki üretim sezonu buğdayın satış fiyatını dikkate almakta ve fiyat kriteri buğday üretimine devam etme veya vazgeçme kararlarında önemli bir etken olmaktadır. Bu durumda da üretiminin sürdürülebilirliğinin sağlanmasında buğday satış fiyatlarının yüksek olması ve fiyatların da öngürülebilirliği önem arz etmektedir. TMO 2011 yilından itibaren kaliteye dayalı alım sistemini uygulamakta ve buğdayın alış fiyatını ürünün kalitesine göre belirlemektedir. Ancak TMO'nun buğday alımındaki bu politika değişikliğine rağmen üreticilerin büyük çoğunluğunun buğday üretim tekniklerinde değişiklik yapmadığı belirlenmiştir. Ayrıca üreticiler TMO'nun kalite kriterlerine göre fiyatlandırma politikasına geçmesine olumlu bakarken üreticilerin TMO'ya götürdüğü buğdayların kalite kriterlerinin altında kalması sonucu satış fiyatının düşük olmasından ise memnun olmadıklarını belirtmişlerdir. Ancak üreticilerin zirai mücadelede gösterdikleri başarı, gübreleme, sertifikalı tohum kullanımı, kaliteli ve verimi yüksek çeşitlere yönelmeleri sayesinde buğdayı daha yüksek fiyattan satma imkanları olabilecektir. Üreticilerin buğdayı sattıkları yer farklı olsa dahi buğday alım politikalarında TMO'nun söz sahibi olmasını istemekte ve TMO'nun buğday alım fiyatlarının tüccarların belirlediği fiyattan daha yüksek olması gerektiğini düşünmektedirler. Ayrıca buğday üreticileri $\mathrm{TMO}$ veya borsaya götürdükleri ürünlerinin düşük fiyattan işlem görse bile nakliye masraflarından dolayı satışını yapmak zorunda kaldıklarını veya ürünü yerinde teslim alan tüccarlara buğdayını sattıklarını ve tüccarın belirlediği buğday satış fiyatına mecburen razı olduklarını belirtmişlerdir. TMO'nun ÇKS'ye kayıtlı ürünün tamamını alma garantisi sunması üreticiler açısından önemli bir uygulama olup ürün satış fiyatı konusunda da üretici memnuniyetinin sağlanması ve TMO ile üretici arasındaki bağın güçlü tutulması önem arz etmektedir. Ayrıca TMO buğday alım politikalarında yapılan değişikliklerin, verimli ve kaliteli buğday çeşitlerinin, kaliteyi ve verimi artırıcı üretim tekniklerinin üreticilere aktarılması konularında yayım çalışmalarına devam edilmesi önerilebilir.

\section{AÇIKLAMA}

Bu makalede 2018 yılına ait araştırma verileri kullanılmış olup, çalışmanın yürütülmesi ve sonuçların yazılması esnasında araştırma ve yayın etiğine uyulmuştur. Herhangi bir "Çıkar Çatışması" bulunmamaktadır. Araştırmada "Katkı Oranına” göre yazar sıralamasına uyulmuştur.

\section{TEŞEKKÜR}

Bu çalışmada; Ankara Üniversitesi Fen Bilimleri Enstitüsü Tarım Ekonomisi Anabilim Dalında tamamlanan "Kamu Buğday Alım Politikalarının Üretici Davranışlarına Etkisinin Araştırılması: Ankara ili Gölbaşı İlçesi Örneği” başlıklı yüksek lisans tezinden elde edilen veriler kullanılmıştır.

\section{KAYNAKLAR}

Anonim, 2015. TMO 2015 Yılı Hububat Sektör Raporu. Anonim, 2017a. Çerkezköy Ticaret ve Sanayi Odası Un ve Unlu Mamuller Sektör Raporu.

Anonim, 2017b. TMO 2017 Yılı Hububat Sektör Raporu. Anonim, 2018. TMO 2018 Yılı Hububat Sektör Raporu.

Anonim, 2020a. Web Sitesi: https://www.tmo.gov.tr/ kurumsal/2/temel-ilkeler (E.T. 10.12. 2020).

Anonim, 2020b. Web Sitesi: https://www.tmo.gov.tr/ Upload/Document/istatistikler/tablolar/1bugdayeuva. pdf (E.T. 10.12.2020).

Akgün, İ., Altındal, D. ve Kara, B. 2011. Isparta Ekolojik Koşullarında Ekmeklik ve Makarnalık Bazı Buğday Çeşitlerinin Uygun Ekim Zamanlarının Belirlenmesi. Tarım Bilimleri Dergisi, 17: 300-309.

Dörtok, A. ve Aksoy, A. 2018. Türkiye Buğday Sektörünün Eşanlı Model Yöntemiyle Tahmini. Türkiye İstatistik Kurumu Kayseri Bölge Müdürlüğü, Atatürk Üniversitesi Ziraat Fakültesi Tarım Ekonomisi Bölümü. KSÜ Tarım ve Doğa Dergisi 21(4):580-586. 
FAO, 2020. Web Sitesi: http://www.fao.org/faostat/ en/\#data/QC (E.T. 04.01.2021).

Karabak, S., Taşcı, R., Acar, O. ve Bozdemir, Ç. 2013. Ankara, Sivas ve Yozgat İllerinde Buğday Üreticilerinin Pazarlama Davranışları. Kafkas Üniversitesi İktisadi Ve İdari Bilimler Fakültesi. 18. Ulusal Pazarlama Kongresi Bildiri Kitabı "Yerel Ekonomilerin Uluslararasılaşmasında Küresel Pazarlamanın Katkısı". Kars.

Karakuş, S. 2017. Toprak Mahsulleri Ofisi'nin Üretici Kararları Üzerindeki Etkisi; Konya İli Çumra İlçesi Örneği. T.C. Selçuk Üniversitesi Fen Bilimleri Enstitüsü Tarım Ekonomisi Anabilim Dalı. Yüksek Lisans Tezi, Konya.

Kaya, M. 2017. Tarımda Lisanslı Depoculuk Sistemi: Hububat Piyasası Örneği. T.C. Kalkınma Bakanlığı, Uzmanlık Tezi.

Kaya, M. 2018. Türkiye Buğday Piyasasında Toprak Mahsulleri Ofisi Alımlarının Ekonometrik Analizi. Gazi Üniversitesi İ.İ.B.F. İktisat Bölümü. Ekonomik Yaklaşım Derneği, 29(106); 73-111.

Konyalı, S. 2008. Türkiye'de Buğdayda Uygulanan Tarım Politikalarının Üreticiler ve Tüketiciler Üzerindeki Etkileri: Trakya Bölgesi Örneği. T.C. Namık Kemal Üniversitesi Fen Bilimleri Enstitüsü Tarım Ekonomisi Anabilim Dalı. Doktora Tezi, Tekirdağ.

Köksal, Ö. ve Cevher, C. 2015. Buğday Tarımında Sertifikalı Tohumluk Tercihini Etkileyen Faktörler Üzerine Bir Araştırma. Tarım Ekonomisi Araştırmaları Dergisi s. 29-39.

Saraçbaşı, T. ve Kutsal, A. 1986. Betimsel İstatistik. Hacettepe Üniversitesi Fen Fakültesi Yayınları, Ders Kitapları Dizisi.

Taşc1, R. ve Oğuz, C. 2014. Buğday Üretim Maliyetleri ve Üreticilerin Çeşit Tercihleri; Ankara İli Haymana İlçesi Örneği. 11. Ulusal Tarım Ekonomisi Kongresi Kitabı, Cilt II s. 606-614, Samsun.

Taşcı, R., Karabak, S., Bolat, M. ve Şanal, T. 2018. Ankara İlinde Un Fabrikalarının Buğday Alım Kriterleri, Üretim ve Pazarlama Yapıları. Tarla Bitkileri Merkez Araştırma Enstitüsü Dergisi, 27(2); 82-91.
Yamane, T. 1967. Elementary sampling theory. New Jersey: Pretice Hall. Inc. Englewood Cliffs. 